\title{
Vliv judikatury Evropského soudu pro lidská práva na systém vojenského soudnictví Spojeného království Velké Británie a Severního Irska*
}

\author{
The Influence of the Case Law of the European \\ Court of Human Rights on the Military Justice System \\ of United Kingdom of Great Britain and Northern Ireland
}

\author{
Ondřej Stypa $^{* *}$
}

\begin{abstract}
Anotace
Clánek pojednává o vlivu Evropského soudu pro lidská práva na podobu vojenského soudnictví Velké Británie a jeho vývoj. Popisuje historický $i$ současný systém vojenského soudnictví Velké Británie. Oba

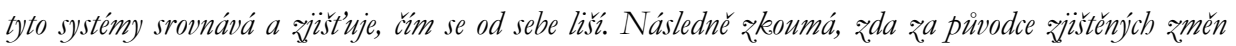
lze považovat Evropský soud pro lidská práva. Článek, za tímto účlem analyzuje relevantní judikaturu ESLP, ale zabývá se též dalšimi možnými príčinami těchto żmèn.
\end{abstract}

Klíčová slova

Vojenské soudnictví; Velká Británie; Evropský soud pro lidská práva.

\section{Abstract}

The article discusses the influence of the European Court of Human Rights on the UK military justice and its development. It describes the historical and current system of military justice in Great Britain. It compares both systems and investigates how do they differ from each other. It then examines whether the European Court of Human Rights can be considered to be the initiator of the identified changes. The article analyses for this purpose the relevant case law of the ECtHR, but also addresses other possible reasons for these changes.

Keywords

Military Justice; Great Britain; European Court of Human Rights.

\section{Úvod}

Evropský soud pro lidská práva (dále též „ESLP“), zrrízený za účelem projednávání porušení práv a svobod vyplývajících z Úmluvy o ochraně lidských práv a základních svobod (dále též „Úmluva“), při své činnosti opakovaně rozhoduje i o koncepčních

\footnotetext{
* Autor v článku publikuje některé závěry své diplomové práce „Vojenské soudnictví ve vybraných členských státech NATO“, za účelem jejich přibližžení širší odborné veřejnosti.

** JUDr. Ondřej Stypa, absolvent, Právnická fakulta, Masarykova univerzita, Brno / Graduate, Faculty of Law, Masaryk University, Brno, Czech Republic / E-mail: 446029@mail.muni.cz
} 
otázkách fungování soudnictví v členských státech Rady Evropy. Jeho rozsudky přiměly radu členských států $\mathrm{k}$ př́jetí reforem upravujících podobu svých justičních systémů. ${ }^{1}$

Tento článek se zaobírá vlivem judikatury ESLP na podobu vojenského soudnictví Velké Británie. Snaží se objasnit, jak se současný model britského vojenského soudnictví liší od toho historického a jakou roli v této proměně hrál Evropský soud pro lidská práva. Zjišt'uje, zda jde o jeden z př́padů, kdy judikatura ESLP vyvolala zásadní reformu institucionálního nastavení soudnictví v členském státě, či zda její vliv na uskutečněné změny byl spíše zanedbatelný. Dalším cílem článku je shrnout obecné požadavky stanovené judikaturou ESLP na podobu a fungování vojenského soudnictví.

V článku vycházím z definice vojenského soudnictví jako samostatné soustavy vojenských soudů. Vojenské soudy jsou jedním z druhů zvláštních soudů. Zvláštní soudy se vyznačují vlastní soudní soustavu, stojící vedle soustavy obecných soudů. Vojenské soudy majî specifickou osobní působnost zahrnující příslušníky ozbrojených sil a v některých př́padech i jejich civilní zaměstnance. Slouží primárně jako trestní soudy. V některých zemích rozhodují i o úzkém okruhu správněprávních věcí a soukromoprávních nároků. ${ }^{2}$

Článek strukturuji následujícím způsobem. V první části popisuji historický (do roku 1996) a současný (rok 2020) systém vojenského soudnictví Velké Británie. Budu se věnovat podobě soudní soustavy vojenských soudů, působnosti vojenských soudů, jmenování a výkonu mandátu soudců a laických členů vojenských soudů, průběhu řízení před vojenskými soudy a opravným prostředkům proti rozhodnutí vojenských soudů. Následně identifikuji, k jakým změnám v systému britského vojenského soudnictví v dané době došlo.

Ve druhé části se věnuji příčinám zjištěných změn. Rozebírám klíčové rozsudky Evropského soudu pro lidská práva týkající se vojenského soudnictví Velké Británie. Zjišt'uji, co v nich Evropský soud pro lidská práva stanovil a jak se v důsledku toho měnilo vojenské soudnictví ve Velké Británii. Pokouším se však hledat i jiné důvody, které mohly vést ke změnám vojenského soudnictví ve Velké Británii.

$\mathrm{Na}$ závěr shrnu požadavky na podobu a fungování vojenských soudů formulované $\mathrm{v}$ judikatuře ESLP a posoudím míru vlivu těchto rozhodnutí na současnou podobu systému vojenského soudnictví Velké Británie.

1 Viz např. KOSAŘ, David. Nudging Domestic Judicial Reforms from Strasbourg. Utrecht Law Review, 2017 , roč. 13 , č. 1 , s. 112-113.

2 KOSAと̌, David. Judicializace justični politiky Evropským soudem pro lidská práva. Praha: Wolters Kluwer, 2016, s. 47. ISBN 978-80-7552-563-5. 


\section{Vývoj vojenského soudnictví Velké Británie}

\subsection{Vojenské soudnictví ve Velké Británii do roku 1996}

Vojenské soudy byly na území Anglie poprvé zř́zeny v roce 1689 v návaznosti na schválení tzv. Mutiny Act. ${ }^{3}$ Britský systém vojenského soudnictví následně převzaly i britské kolonie a stal se archetypem vojenského soudnictví v zemích právní tradice common law. Výrazně ovlivnil například vývoj a podobu vojenského soudnictví v USA. ${ }^{4} \mathrm{~V}$ samotné Velké Británii vydržel tento historický systém vojenského soudnictví s dílčími změnami až do roku $1997 .{ }^{5}$ V roce 1996 proto ve Velké Británii neexistovala jednotná soustava vojenských soudů prvního stupně pro celé ozbrojené síly. Jednotlivé složky ozbrojených sil, tj. armáda, letectvo a námoŕnictvo, zrrizovaly vlastní vojenské soudy prvního stupně. Všechny tyto soudy byly svolávány ad hoc a neměly stálou povahu. Druhý stupeň soudní soustavy vojenských soudů tvořil Vojenský odvolací soud (Court Martial Appeal Court). Šlo o soud stálý a společný všem složkám ozbrojených sil. ${ }^{6}$

Vojenské soudy byly výhradně trestními soudy. Př́slušela jim pravomoc soudit trestné činy př́islušníků ozbrojených sil a vybraných skupin civilistů. Šlo především o zaměstnance ozbrojených sil a osoby žijící na vojenských základnách. Trestné činy př́slušníků ozbrojených sil nemající souvislost se službou v ozbrojených silách mohly vojenské soudy soudit pouze tehdy, pokud byly spáchány v zahraničí. ${ }^{7}$

Zajímavý aspekt tohoto modelu představovala skutečnost, že judge advocate, ${ }^{8}$ tedy soudce vojenského soudu, měl v řízení pouze poradní funkci a nemohl se podílet na rozhodování o vině a trestu. Judge advocate byl jmenován ministrem spravedlnosti (Lord Chancellor) ${ }^{10}$ a jeho funkce zanikala až dosažením důchodového věku. Ministr spravedlnosti ho mohl odvolat pro nevhodné chování nebo pro neschopnost vykonávat

3 ANDREU-GUZMAN, Frederico. Military jurisdiction and international law. Geneva: International Commission of Jurists, 2004, s. 341. ISBN 978-9290371021.

4 MORRIS, Lawrence J. Military Justice: A Guide to the Issues. Santa Barbara: Praeger Security International, 2010, s. 2, 14 a 16. ISBN 978-0275993665.

5 RANT, James W. The military justice system and human rights. The RUSI Journal, 2000, roč. 145, č. 2, s. 32. DOI: https://doi.org/10.1080/03071840008446505

6 ANDREU-GUZMAN, Frederico. Military jurisdiction and international law. Geneva: International Commission of Jurists, 2004, s. 341. ISBN 978-9290371021.

7 FIDELL, Eugene R. Military justice: a very short introduction. Oxford: Oxford University Press, 2016 , s. 44. ISBN 978-0-19-930349-6.

8 Tento výraz nemá český ekvivalent a neexistuje k němu český překlad, pročež ho nepřekládám a užívám ho v původním znění.

9 Rozsudek Evropského soudu pro lidská práva ze dne 25. 2. 1997, Findlay proti Spojenému království, č. stížnosti $22107 / 93$, bod 44 .

10 Section 30 of Courts-Martial Appeals Act 1951 [Spojené království Velké Británie a Severního Irska] as amended on 1.1.1996. 
funkci. ${ }^{11}$ Judge advocate musel před jmenováním do funkce disponovat několikaletou zkušeností z jiných právnických profesí. ${ }^{12}$ Judge advocate u vojenských soudů armády a letectva byl civilista, $\mathrm{v}$ př́padě námořnictva se jednalo o vojenského důstojníka. ${ }^{13}$ Vojenský odvolací soud tvořili soudci obecných soudů vyššího stupně. ${ }^{14}$

Rozhodující úlohu měl v tomto systému vojenského soudnictví velící důstojník. V př́pravném řízení prováděl úvodní vyšetřování a rozhodoval o podání obžaloby i o jejím obsahu. Následně jako svolávací důstojník (convening officer) svolával vojenský soud a vybíral členy poroty ad hoc ke každému př́ípadu. Takto vytvořená porota rozhodovala o vině i trestu, zatímco judge advocate jakožto soudce měl pouze poradní funkci. Svolávací důstojník navíc mohl soudní ř́zení v dané věci kdykoliv zastavit. Poté, co vojenský soud prvního stupně vynesl rozsudek, jej velící důstojník, jako potvrzovací důstojník (confirming officer), přezkoumával a mohl ho zrušit nebo změnit. ${ }^{15}$

Proti rozsudku vojenského soudu prvního stupně mohl obžalovaný podat odvolání k Odvolacímu vojenskému soudu. Předtím však musel podat žádost o přezkum k přezkumnému orgánu (Reviewing Authority) Rady obrany Spojeného království (Defence council of the United Kingdom), jež je součástí ministerstva obrany. ${ }^{16}$ Vojenský odvolací soud měl diskreci rozhodnout o tom, zda se odvoláním bude meritorně zabývat. Navrhnout přezkoumání určitého př́padu po právní stránce mohl Vojenskému odvolacímu soudu i Judge Advocate General, tedy velitel právní služby př́slušné složky ozbrojených sil. ${ }^{17}$ Obžalovaný rovněž disponoval možností podat mimořádný opravný prostředek ke Sněmovně lordů (House of Lords), která v té době sloužila jako nejvyšší soud Velké Británie. ${ }^{18}$

\subsection{Vojenské soudnictví ve Velké Británii v roce 2020}

Velká Británie v současnosti disponuje jednotnou soustavou vojenských soudů pro všechny složky svých ozbrojených sil, tj. armádu, námořnictvo i letectvo. Všechny vojenské soudy Velké Británie jsou soudy stálými. ${ }^{19}$

11 Section 32 of Courts-Martial Appeals Act 1951 [Spojené království Velké Británie a Severního Irska] as amended on 1.1.1996.

12 Ibid., section 31.

13 Rozsudek velkého senátu Evropského soudu pro lidská práva ze dne 16. 12. 2003, Grieves proti Spojenému království, č. stížnosti 57067/00, bod 82.

14 Section 2 of Courts-Martial Appeals Act 1968 [Spojené království Velké Británie a Severního Irska] as amended on 1.1.1996.

15 ANDREU-GUZMAN, Frederico. Military jurisdiction and international law. Geneva: International Commission of Jurists, 2004, s. 343-344. ISBN 978-9290371021.

16 Section 9 of Courts-Martial Appeals Act 1968 [Spojené království Velké Británie a Severního Irska] as amended on 1.1.1996.

17 Ibid., section 34.

18 Ibid., section 339.

19 Paragraph 19 of Armed Forces Act 2006 Explanatory Notes, Overview of the Act [Spojené království Velké Británie a Severního Irska]. 
Soustava britských vojenských trestních soudů se skládá z Vojenského soudu (Court Martial) v prvním stupni ${ }^{20}$ a Vojenského odvolacího soudu (Court Martial Appeal Court) ve druhém stupni. ${ }^{21}$ Soustavu vojenských soudů doplňuje ještě Odvolací soud pro sumární řízení (Summary Appeal Court), jenž je vojenským správním soudem, rozhodujícím o opravných prostředcích podaných proti rozhodnutím velitele o disciplinárních deliktech, vydávaných v sumárním řízení. ${ }^{22}$

Vojenské soudy mají působnost nad profesionálními př́islušníky ozbrojených sil a vojáky v záloze v době, kdy jsou povoláni do služby, ${ }^{23}$ a př́slušníky vojenských sil zámořských teritorií Velké Británie, pokud jsou zařazeni do služby v ozbrojených silách Velké Británie. ${ }^{24}$ Vojenské soudy mají jurisdikci i nad civilisty podléhajícím služební kázni. ${ }^{25}$ Primárně jde o zaměstnance ozbrojených sil nacházející se ve vojenských prostorech a osoby, jež tam s nimi žijí. ${ }^{26}$ Územní působnost vojenských soudů na civilisty podléhající služební disciplíně je však na rozdíl od minulosti omezena pouze na britské ostrovy. V zahraničí náleží uvedené osoby od roku 2009 do působnosti Služebního civilního soudu (Service Civilian Court). ${ }^{27}$

Soudce Vojenského soudu či Odvolacího soudu pro sumární řízení je označován jako judge advocate. Judge advocate je jmenován ministrem spravedlnosti na základě doporučení Komise pro výběr soudců (Judicial Appointment Commission), ${ }^{28}$ což je nezávislý patnáctičlenný orgán složený ze soudců, př́slušníků právnických profesí a laiků pověřený výběrem kandidátů na funkci soudce. ${ }^{29}$ Kandidát na pozici judge advocate musí po dobu alespoň pěti let působit jako barrister ${ }^{30}$ či solicitor. ${ }^{31}$ Judge advocate je civilista nepodléhající

20 Section 154 (1) of Armed Forces Act 2006 [Spojené království Velké Británie a Severního Irska] as amended.

21 Section 8 of Courts-Martial Appeals Act 1968 [Spojené království Velké Británie a Severního Irska] as amended.

22 Sections 140-141 of Armed Forces Act 2006 [Spojené království Velké Británie a Severního Irska] as amended.

23 Ibid., section 367.

24 Ibid., section 369.

25 Section 370, of Armed Forces Act 2006 [Spojené království Velké Británie a Severního Irska] as amended.

26 Ibid., schedule 15 , sections 4, 8-9.

27 Ibid., section 51.

28 Section 30 of Courts-Martial Appeals Act 1951 [Spojené království Velké Británie a Severního Irska] as amended a Sections 85-87 of Constitutional Reform Act 2005 [Spojené království Velké Británie a Severního Irska] as amended.

29 Sections 26-27 of Constitutional Reform Act 2005 [Spojené království Velké Británie a Severního Irska] as amended.

30 Barrister a solicitor jsou označení pro právnická povolání ve Velké Británii, jejichž náplň práce je do jisté míry obdobou advokacie. Pro větši přesnost budu dále užívat obou výrazů v původním znění.

31 Section 30 of Courts-Martial Appeals Act 1951 [Spojené království Velké Británie a Severního Irska] as amended a Section 50 of Tribunals, Courts and Enforcement Act 2007 [Spojené království Velké Británie a Severního Irska] as amended. 
vojenské kázni ani subordinaci. Pro jmenování do funkce tedy musí splňovat stejná kvalifikační kritéria jako soudci u obecných soudů prvního stupně (district judges). ${ }^{32}$

Soudce Vojenského odvolacího soudu vybírá Lord Chief Justice z řad soudců Odvolacího soudu (Court of appeal) a Vrchního soudu (High court). ${ }^{33}$ Lord Chief Justice ${ }^{34}$ je předseda trestní divize Odvolacího soudu, jenž z titulu své funkce tradičně stojí v čele britského soudnictví, které reprezentuje navenek. ${ }^{35}$ Soudci vojenského odvolacího soudu jsou soudci již dříve jmenovaní k civilním soudům a nijak nepodléhají ozbrojeným silám.

Judge advocate má stálý mandát, avšak jeho funkce zaniká dosažením důchodového věku sedmdesáti let. ${ }^{36}$ Ze své funkce může být odvolán pro neschopnost vykonávat funkci soudce nebo pro nevhodné chování. Za dané prohřešky ho může odvolat pouze ministr spravedlnosti, pokud s tím souhlasí Lord Chief Justice. ${ }^{37}$ To, zda se judge advocate choval nevhodným způsobem, posuzuje Úřad pro vyšetřování justičních stížností (Judicial Complaints Investigations Office), tedy nezávislý vyšetřovací orgán, který následně zašle svá zjištění ministru spravedlnosti s doporučením, jak s dotyčným naložit. ${ }^{38}$

Délka mandátu judge advocate a důvody, pro které může být odvolán, jsou totožné jako u soudců obecných soudů. Tato pravidla se vztahují i na soudce Vojenského odvolacího soudu, který ostatně tvoří soudci obecných soudů vyšších stupňu․ ${ }^{39}$

Členy poroty Vojenského soudu a Odvolacího soudu pro sumární řízení vybírá obdobným způsobem jako porotu u civilních soudů Court Administration Officer, jakožto ředitel vojenské soudní služby (Military court service). ${ }^{40}$ Vojenská soudní služba je orgánem státní správy soudů, přičemž od svého civilního ekvivalentu (Her Majesty's Courts and Tribunals Service) se liší jen tím, že spadá pod ministerstvo obrany místo ministerstva

32 Section 9 of County Courts Act 1984 [Spojené království Velké Británie a Severního Irska] as amended a Section 50 of Tribunals, Courts and Enforcement Act 2007 [Spojené království Velké Británie a Severního Irska] as amended.

33 ANDREU-GUZMAN, Frederico. Military jurisdiction and international law. Geneva: International Commission of Jurists, 2004, s. 347-348. ISBN 978-9290371021.

34 Pro tuto funkci opět neexistuje český ekvivalent ani ustálený překlad, a proto tento výraz nepřekládám a užívám ho v původním znění. Přestože Lord Chief Justice je nejen hlavou britského soudnictví, ale i soudním funkcionářem Odvolacího soudu, nejde o předsedu daného soudu.

35 Section 7 of Constitutional Reform Act 2005 [Spojené království Velké Británie a Severního Irska] as amended.

36 Section 32 (2) of Courts-Martial Appeals Act 1951 [Spojené království Velké Británie a Severního Irska] as amended.

37 Section 32 (1B) of Courts-Martial Appeals Act 1951 [Spojené království Velké Británie a Severního Irska] as amended.

38 Judicial conduct. Judiciary.uk [online]. [cit. 29. 2. 2020]. Dostupné z: https://www.judiciary.uk/ about-the-judiciary/the-judiciary-the-government-and-the-constitution/jud-acc-ind/jud-conduct/

39 Section 11 of Senior Courts Act 1981 [Spojené království Velké Británie a Severního Irska] as amended.

40 Section 155 (6) of Armed Forces Act 2006 [Spojené království Velké Británie a Severního Irska] as amended. 
spravedlnosti. Vojenská soudní služba je tvořena civilními úředníky nepodléhajícími ozbrojeným silám. ${ }^{41}$

Úvodní vyšetřování trestné činnosti př́islušníků ozbrojených sil provádí služební policie (Service Police), která nepodléhá velení velícího důstojníka podezřelého. ${ }^{42}$ Její práci, jakož i samotné prrípravné řízení trestní řídí služební prokuratura (Service Prosecuting Authority), která rovněž rozhoduje o podání obžaloby. ${ }^{43}$ Judge advocate, jakožto soudce vojenského soudu prvního stupně, rozhoduje o vzetí obviněného do vazby a o domovních prohlídkách. ${ }^{44}$

Vojenský soud tvoři judge advocate a porota složená podle závažnosti projednávaného činu z tří až sedmi laických členů. ${ }^{45}$ Judge advocate řídí průběh soudního procesu, rozhoduje o právních otázkách a poskytuje poučení laickým členům soudu. ${ }^{46} \mathrm{O}$ vině obžalovaného rozhoduje porota prostou většinou hlasů. $V$ prŕpadě rovnosti hlasů je obžaloba zamítnuta. Judge advocate se nemůže účastnit rozhodování o vině, ale podílí se s laickými členy na rozhodnutí o trestu, přičemž v prrípadě rovnosti hlasů má rozhodující hlas. ${ }^{47}$

Odvolací soud pro sumární řízení tvoří judge advocate a dva laičtí členové. Slouží jako správní soud přezkoumávající rozhodnutí velících důstojníků ve věcech disciplinárních deliktů. Odvolací soud pro sumární řizení může napadené rozhodnutí velícího důstojníka o disciplinárním deliktu zrušit, potvrdit či změnit. Soud o tom rozhoduje prostou většinou, hlasy laických členů i judge advocate mají stejnou váhu. ${ }^{48}$

Proti rozsudku Vojenského soudu může obžalovaný podat odvolání k Vojenskému odvolacímu soudu v otázce viny i trestu. ${ }^{49}$ Generální prokurátor (Attorney General) ${ }^{50}$ může podat odvolání proti rozsudku Vojenského soudu pouze ohledně výše trestu. Vojenský odvolací soud zasedá v senátu složeném minimálně ze tří soudců, přičemž soudců musí

41 The Military Court Service. Gov.uk [online]. [cit. 29. 2. 2020]. Dostupné z: https://www.gov.uk/ guidance/the-military-court-service

42 Section 113 of Armed Forces Act 2006 [Spojené království Velké Británie a Severního Irska] as amended.

43 ANDREU-GUZMAN, Frederico. Military jurisdiction and international law. Geneva: International Commission of Jurists, 2004, s. 343. ISBN 978-9290371021.

44 Section 101 (1) and section 105 (3) of Armed Forces Act 2006 [Spojené království Velké Británie a Severního Irska] as amended.

45 Ibid., section 154 (1), (2).

46 Ibid., section 159.

47 Ibid., section 160.

48 Sections 142, 147 and 149 of Armed Forces Act 2006 [Spojené království Velké Británie a Severního Irska] as amended.

49 Section 8 of Courts-Martial Appeals Act 1968 [Spojené království Velké Británie a Severního Irska] as amended.

50 Britský generální prokurátor (Attorney General) slouží jako hlavní poradce britské vlády v právních otázkách. Na rozdíl od svého stejnojmenného protějšku v USA není ministrem spravedlnosti. Britský ministr spravedlnosti je označován jako Lord Chancellor and secretary of state for justice. 
být vždy lichý počet. Vojenský odvolací soud může napadený rozsudek potvrdit, změnit nebo zrušit a vrátit Vojenskému soudu k dalšímu rrízení. ${ }^{51}$

Proti rozhodnutí Vojenského odvolacího soudu lze podat mimořádný opravný prostředek k Nejvyššímu soudu (Supreme court). Mimořádný opravný prostředek spočívá v tom, že je Nejvyššímu soudu k posouzení předložena právní otázka, která se vyskytla v dosavadním řízení. Předložit právní otázku k posouzení Nejvyššímu soudu může obžalovaný nebo generální prokurátor. Právní otázka může být Nejvyššímu soudu předložena pouze na základě rozhodnutí Vojenského odvolacího soudu nebo Nejvyššího soudu o př́pustnosti mimořádného opravného prostředku. Toto rozhodnutí je vydáno pouze v prípadě, že jde o právní otázku mající obecný význam nebo ji Nejvyšší soud sám posoudí jako otázku, jíž by se měl zabývat. ${ }^{52}$

Proti rozhodnutí Odvolacího soudu pro sumární řízení, tj. vojenského správního soudu rozhodujícího o odvoláních proti rozhodnutím o disciplinárních deliktech, mohou navrhovatel i odpůrce (tj. důstojník, který vydal napadené disciplinární rozhodnutî) podat opravný prostředek v podobě žádosti o přezkum rozhodnutí k civilnímu Vrchnímu soudu. Opravný prostředek má kasační charakter. Vrchní soud může rozhodnutí Odvolacího soudu pro sumární řízení přezkoumat pouze po právní stránce. ${ }^{53}$

\subsection{Srovnání vojenského soudnictví Velké Británie v roce 1996 a v roce 2020}

Nyní můžeme přistoupit ke komparaci historického a současného systému britského vojenského soudnictví. Za účelem srovnání těchto systémů identifikuji změny, k nimž došlo ve výše popsaných oblastech vojenského soudnictví, tj. podobě soudní soustavy vojenských soudů, působnosti vojenských soudů, jmenování a výkonu mandátu soudců a laických členů vojenských soudo̊, průběhu řízení před vojenskými soudy a opravným prostředkům proti rozhodnutí vojenských soudů.

Mezi tyto změny patři vytvoření jednotné soustavy vojenských soudů společné pro všechny složky ozbrojených sil a stálá povaha vojenských soudů prvního stupně. Díky zř́zení Odvolacího soudu pro sumární řízení nyní mají vojenské soudy působnost i ve správněprávních otázkách. V trestněprávních záležitostech se jejich místní působnost rozšíríla o trestné činy vojáků spáchané v zahraničí. Došlo však k omezení územní působnosti vojenských soudů na civilisty podléhající civilní kázni.

Ministr spravedlnosti ztratil pravomoc vybírat soudce vojenských soudů ve prospěch nezávislého orgánu, jímž je Komise pro výběr soudců. Odvolat tyto soudce může ministr nyní již jen se souhlasem soudního funkcionáře, a to na doporučení nezávislého vyšetřovacího orgánu.

51 Section 273 of Armed Forces Act 2006 [Spojené království Velké Británie a Severního Irska] as amended.

52 Ibid., section 274.

53 Ibid., section 149 (2). 
Došlo k posílení postavení judge advocates, jakožto soudců vojenského soudu prvního stupně. Rozhodují o procesních otázkách a podílí se na rozhodování o trestu. Naopak výrazně oslabila pozice velícího důstojníka. Již nerozhoduje o podání obžaloby, nevybírá členy poroty a ani nemůže změnit rozsudek vojenského soudu prvního stupně. Pravomoc podávat opravné prostředky za stranu žaloby přešla z velitele právní služby na generálního prokurátora.

Celkem tedy lze identifikovat dvanáct změn. Pro přehlednost je shrnuji níže v tabulce pomocí komparačních otázek.

\begin{tabular}{|c|c|c|}
\hline Komparační otázky & $\begin{array}{l}\text { Velká Británie } \\
1996\end{array}$ & $\begin{array}{l}\text { Velká Británie } \\
2020\end{array}$ \\
\hline $\begin{array}{l}\text { Existuje jednotná soustava vojenských soudů } \\
\text { pro celé ozbrojené síly? }\end{array}$ & ne & ano \\
\hline Jaká je věcná působnost vojenských soudů? & trestněprávní & $\begin{array}{l}\text { trestněprávní } \\
\text { a správněprávní }\end{array}$ \\
\hline $\begin{array}{l}\text { Jaká je územní působnost vojenských soudů } \\
\text { nad civilisty podléhající služební kázni? }\end{array}$ & univerzální & $\begin{array}{l}\text { omezená } \\
\text { na území } \\
\text { Velké Británie }\end{array}$ \\
\hline $\begin{array}{l}\text { Jsou vojenské soudy prvního stupně zřizovány jako } \\
\text { soudy stálé, nebo ad hoc? }\end{array}$ & ad hoc & stálé \\
\hline $\begin{array}{l}\text { Mohou vojenské soudy soudit i trestné činy vojáků } \\
\text { spáchané bez souvislosti se službou v ozbrojených } \\
\text { silách? }\end{array}$ & $\begin{array}{l}\text { ne (s výjimkou } \\
\text { činů spáchaných } \\
\text { v zahraničíi) }\end{array}$ & ano \\
\hline Kdo vybírá soudce vojenských soudů? & ministr & nezávislý orgán \\
\hline $\begin{array}{l}\text { Má soudce vojenského soudu prvního stupnè } \\
\text { poradní, nebo rozhodovací pravomoci? }\end{array}$ & poradní & rozhodovací \\
\hline Kdo může odvolat soudce vojenských soudů? & ministr & $\begin{array}{l}\text { ministr } \\
\text { se soudním } \\
\text { funkcionářem }\end{array}$ \\
\hline Kdo vybírá laické členy vojenských soudů? & velící důstojník & $\begin{array}{l}\text { orgán státní } \\
\text { správy soudů }\end{array}$ \\
\hline $\begin{array}{l}\text { Kdo rozhoduje o podání obžaloby k vojenskému } \\
\text { soudu? }\end{array}$ & velící důstojník & prokurátor \\
\hline $\begin{array}{l}\text { Může velící důstojník změnit rozsudek vojenského } \\
\text { soudu? }\end{array}$ & ano & ne \\
\hline $\begin{array}{l}\text { Kdo může podat opravný prostředek proti rozsudku } \\
\text { vojenského soudu? }\end{array}$ & $\begin{array}{l}\text { obžalovaný } \\
\text { a velitel právní } \\
\text { služby }\end{array}$ & $\begin{array}{l}\text { obžalovaný } \\
\text { a prokurátor }\end{array}$ \\
\hline
\end{tabular}

Změny týkající se pravomocí velícího důstojníka a stálosti vojenských soudů v sobě skrývají zajímavý aspekt. Jde o prvky sloužící k odlišení modelů vojenského soudnictví na Common law model a kontinentální model. Ad hoc povaha vojenských soudů a výrazné pravomoci velícího důstojníka v řízení před vojenským soudem jsou typickými 
znaky Common law modelu vojenského soudnictví. Naopak kontinentální model vojenského soudnictví se vyznačuje stálými vojenskými soudy a minimálními pravomocemi velícího důstojníka. ${ }^{54}$

Lze tedy uvažovat, zda lze vojenské soudnictví Velké Británie raadit do Common law modelu vojenského soudnictví. Na druhou stranu si Velká Británie uchovala řadu prvků typických pro Common law model vojenského soudnictví jako napr. soudní porotu ${ }^{55}$ a laterální model výběru soudců. ${ }^{56}$

Přesto již jen skutečnost, že jde o př́slušnosti britského vojenského soudnictví do Common law modelu vojenského soudnictví pochybovat, dokresluje rozsah a význam proběhnuvších změn. Common law model vojenského soudnictví se totiž utvářel na základě historického systému britského vojenského soudnictví.

\section{Př́íčiny změn vojenského soudnictví Velké Británie}

V této části článku zjišst’uji, co vyvolalo změny v britském vojenském soudnictví. Nejprve se zabývám rozsudky Evropského soudu pro lidská práva týkající se britského vojenského soudnictví. Postupně rozebírám rozsudky ESLP ve věcech Findlay, Morris, Cooper, Grieves a Martin. Stručně představím skutkový děj, uvedu, zda Evropský soud pro lidská práva shledal v daném prrípadě porušení práv vyplývajících z Úmluvy o ochraně lidských práv a základních svobod (dále též „Úmluva“) a v čem toto porušení spatřoval.

Následně uvedu, jaké změny britského vojenského soudnictví tato rozhodnutí ESLP vyvolala a zda jsou tyto změny jejich přímým nebo nepřímým důsledkem. Za přímý důsledek považuji změnu přijatou na základě toho, že ESLP shledal původní úpravu $\mathrm{v}$ rozporu s Úmluvou. Za neprrímý důsledek změnu vyvolanou jinou změnou přijatou na základě výtky ESLP a př́pady, kdy ESLP označil určitou úpravu za problematickou, ale danou otázkou se dále nezabýval, nebot' porušení Úmluvy v daném př́ípadě našel již jinde.

Mezi změny vyvolané vlivem Evropského soudu pro lidská práva zahrnuji i změny provedené těsně před vynesením rozsudku ESLP, přijaté v návaznosti na podání stížnosti či poté, co Evropská komise pro lidská práva konstatovala, že došlo k porušení práva vyplývajícího z Úmluvy, pokud ESLP její závěry následně potvrdil. V posledním oddílu této podkapitoly popisuji změny britského vojenského soudnictví, jež nejsou důsledkem judikatury ESLP.

54 VASHAKMADZE, Mindia. Understanding Military Justice: A Practice Note, Geneva: The Geneva Centre for the Democratic Control of Armed Forces, 2018, s. 4. ISBN 92-9222-452-2.

55 Ibid.

56 KOSǍ̌, David. Judicializace justični politiky Evropským soudem pro lidskáa práva. Praha: Wolters Kluwer, 2016. s. 65. ISBN 978-80-7552-563-5. 


\subsection{Klíčová rozhodnutí ESLP týkající se vojenského soudnictví Velké Británie}

V případu Findlay proti Spojenému královstvi řešil Evropský soud pro lidská práva stížnost Alexandra Findlayho, vojáka skotské gardy, na porušení práva na nezávislý a nestranný tribunál. Toto právo mělo být porušeno řízením u Vojenského soudu armády, který ho v roce 1991 uznal vinným z napadení a nebezpečného vyhrožování ostatním př́slušníkům své jednotky. Stěžovatel po vyčerpání opravných prostředků podal v roce 1993 stížnost k Evropské komisi pro lidská práva, která v roce 1995 v dané věci jednomyslně konstatovala porušení Úmluvy a věc předala ESLP. Šlo o první případ týkající se britského vojenského soudnictví, který byl předložen ESLP. ${ }^{57}$

ESLP vynesl v roce 1997 rozsudek, v němž jednomyslně ve věci Findlay shledal porušení práva na nezávislý a nestranný tribunál. Toto porušení spatřoval ESLP v rozsáhlých pravomocích velícího důstojníka ve vztahu k řízení u vojenských soudů. Konkrétně v tom, že velící důstojník rozhodoval o podání a obsahu obžaloby, svolání Vojenského soudu, výběru členů tohoto soudu a rozhodnutí soudu podléhalo přezkumu z jeho strany a vyžadovalo jeho potvrzení k nabytí účinnosti. Členové Vojenského soudu vybraní velícím důstojníkem navíc postrádali právnické vzdělání a měli nižší hodnost než velící důstojník. ${ }^{58}$ ESLP rovněž konstatoval, že př́tomnost judge advocate, jakožto ekvivalentu soudce, nepredstavovala dostatečnou záruku nezávislosti vojenského soudu, nebot' dotyčný měl pouze poradní funkci a nijak se nepodílel na rozhodování soudu. ${ }^{59}$

Několik let po rozsudku v př́padu Findlay následovaly v rychlém sledu po sobě rozsudky ve věcech Morris, Cooper a Grieves. V nich se Evropský soud pro lidská práva postupně zabýval vojenskými soudy každé ze složek ozbrojených sil Velké Británie. V případu Morris proti Spojenému královstvi se ESLP zabýval stížností vojáka britské armády, který byl v roce 1997 Vojenským soudem armády uznán vinným ze svémocného odloučení od jednotky. Řízení před Vojenským soudem armády probíhala již podle nových pravidel, která v daném roce nabyla účinnosti. Odsouzený podal po vyčerpání opravných prostředků na konci roku 1997 stížnost k Evropské komisi pro lidská práva pro porušení práva na nezávislý a nestranný tribunál. Poté, co v listopadu 1998 nabyl účinnosti protokol č. 11 k Úmluvě o ochraně lidských práv a základních svobod, byla stížnost automaticky postoupena ESLP.

Evropský soud pro lidská práva v dané věci vynesl rozsudek v roce 2002 a konstatoval, že došlo k porušení práva podle článku 6 odst. 1 Úmluvy. ESLP se nejprve vyjádřil ke změnám provedeným v britském vojenském soudnictví v roce 1997 a uvedl,

57 RANT, James W. The military justice system and human rights. The RUSI Journal, 2000, roč. 145, č. 2, s. 32. DOI: https://doi.org/10.1080/03071840008446505

58 Rozsudek Evropského soudu pro lidská práva ze dne 25. 2. 1997, Findlay proti Spojenému království, rozsudek č. stížnosti 22107/93, body 72-77.

59 Ibid., bod 78 . 
že výběr laických členů vojenských soudů orgánem státní správy soudů a posílené postavení judge advocate nepředstavují zásah do práva na nezávislý a nestranný tribunál. Nově vytvořenou funkci stálého předsedy Vojenského soudu, tedy laického důstojníka přiděleného $\mathrm{k}$ Vojenskému soudu na dobu čtyř let, ESLP rovněž nepovažoval za porušení úmluvy, nebot' post stálého předsedy představoval pro svého držitele poslední funkci zastávanou před odchodem do výslužby. Stálý předseda navíc nepodléhal posloupnosti vojenského velení. Působil jako předseda poroty a předsedal ř́zení u Vojenského soudu, ale nebyl soudním funkcionářem. ${ }^{60}$

ESLP však spatřoval porušení práva na nezávislý a nestranný tribunál v tom, že ad hoc jmenovaní laičtí členové soudu nebyli dostatečně proškoleni v právních otázkách, podléhali vojenské kázni, měli relativně nízkou hodnost a museli o svém působení na vojenských soudech podávat hlášení svým nadřízeným. ESLP dále uvedl, že postavení laických členů Vojenského soudu, kteří jsou př́slušníky ozbrojených sil, není srovnatelné se členy civilní poroty, kteří nejsou vystaveni takovému vnějšímu tlaku. ${ }^{61}$ Tím soud se facto dovodil, že laičtí členové vojenských soudů musí mít zajištěnu větší míru nezávislosti než jejich civilní protějšky.

Evropský soud pro lidská práva se $\mathrm{v}$ dané věci rovněž zabýval rolí Rady obrany Spojeného království, jejíž přezkumný orgán automaticky přezkoumával všechna rozhodnutí Vojenského soudu a mohl je zrušit. ESLP poukázal na to, že z jeho judikatury $^{62}$ vyplývá, že soudní rozhodnutí nesmí být změněno nebo zrušeno orgánem, který nemá charakter soudu, což přezkumný orgán Rady obrany nesplňuje. ${ }^{63}$

V př́padu Cooperproti Spojenému královstvíse velký senát Evropského soudu pro lidská práva zabýval vojenským soudnictvím britského královského letectva. Stěžovatel byl v roce 1998 Vojenským soudem RAF uznán vinným z krádeže na vojenské základně, proti čemuž se bránil opravnými prostředky, kteréžto pokusy kulminovaly podáním stížnosti k ESLP v roce 1999 pro porušení práva podle článku 6 odst. 1 Úmluvy.

ESLP v dané věci neshledal porušení práv vyplývajících z Úmluvy o ochraně lidských práv a základních svobod. Zopakoval své závěry z případu Morris o tom, že pozice judge advocate a stálého laického předsedy, jakoži způsob výběru laických členů soudů jsou kompatibilní s Úmluvou. ${ }^{64}$ Hlavním důvodem, proč v tomto př́padě rozhodl odlišně než ve věci Morris,

60 Rozsudek Evropského soudu pro lidská práva ze dne 26. 2. 2002, Morris proti Spojenému kerálovství, č. stížnosti 38784/97, body 66-71.

61 Ibid., bod 72 .

62 Např. Rozsudek Evropského soudu pro lidská práva ze dne 25. 2. 1997, Findlay proti Spojenému království, č. stížnosti 22107/93, bod 77 a rozsudek velkého senátu Evropského soudu pro lidská práva ze dne 28. 10. 1999, Brumarescu proti Rumunsku, č. stížnosti 28342/95, bod 61.

63 Rozsudek Evropského soudu pro lidská práva ze dne 26. 2. 2002, Morris proti Spojenému kerálovství, č. stížnosti 38784/97, body 73-75.

64 Rozsudek velkého senátu Evropského soudu pro lidská práva ze dne 16. 12. 2003, Cooper proti Spojenému království, č. stížnosti 48843/99, body 117-118. 
bylo odlišné postavení řadových laických členů vojenského soudu. Nedostatek jejich právní kvalifikace kompenzovalo podrobné poučení od judge advocate a informační zprávy od Kanceláře Vojenského soudu RAF (Royal Air Force’s Courts Martial Administration Unit) týkající se jejich práv a povinností v řízení u Vojenského soudu RAF. ${ }^{65}$ Další záruku nezávislosti laických členů vojenského soudu spatřoval ESLP v tom, že vojáci plnící roli členů Vojenského soudu měli výslovně zakázáno komukoliv sdělovat, jak v př́padu hlasovali a nesměli být za své rozhodování u Vojenského soudu RAF postihováni. ${ }^{66}$

ESLP se rovněž znovu zabýval rolí přezkumného orgánu Rady obrany Spojeného království. Vyjádřil znepokojení nad tím, že mimosoudní orgán může zrušit soudní rozhodnutí, avšak tentokrát v tom neshledal porušení Úmluvy, nebot' konečné rozhodnutí ve věci náleželo Vojenskému odvolacímu soudu. ${ }^{67}$ Tento závěr ostře kontrastuje s rozhodnutím ve věci Morris, kde ESLP označil obdobnou situaci za porušení Úmluvy. ${ }^{68}$

Stejný den rozhodoval velký senát ESLP i o stížnosti v případu Grieves proti Spojenému království, v němž stěžovatel napadal systém vojenského soudnictví britského královského námořnictva, který ho uznal vinným z těžkého ublížení na zdraví. Na rozdíl od případu Cooper však ESLP v prrípadu Grieves konstatoval porušení práv vyplývajících z článku 6 odst. 1 Úmluvy o ochraně lidských práv a základních svobod.

ESLP identifikoval u Vojenského soudu námořnictva několik odlišností od Vojenského soudu letectva, které podle něj představovaly porušení práva na nezávislý a nestranný tribunál. První problém spatřoval ESLP v tom, že kvưli absenci stálého předsedy měl Vojenský soud námořnictva zcela povahu ad hoc tribunálu. ${ }^{69}$ Porušení Úmluvy shledal soud také ve skutečnosti, že judge advocate u Vojenského soudu námořnictva byl vojenským důstojníkem právní služby a plnil i úkoly nemající souvislost s jeho působením u Vojenského soudu. ${ }^{70}$

ESLP uvedl, že chybí přesvědčivé vysvětlení, proč judge advocates u Vojenského soudu námořnictva musí být př́slušníky ozbrojených sil, když judge advocates u Vojenském soudu armády a Vojenském soudu letectva jsou civilisté. Vzhledem k absenci přesvědčivých důvodů pro tento stav nelze dle názoru ESLP judge advocates britského královského námořnictva považovat za dostatečnou záruku nezávislosti Vojenského soudu

65 Rozsudek velkého senátu Evropského soudu pro lidská práva ze dne 16. 12. 2003, Cooper proti Spojenému keálovství, č. stížnosti 48843/99, body 123-124.

66 Ibid., bod 125.

67 Rozsudek velkého senátu Evropského soudu pro lidská práva ze dne 16. 12. 2003, Cooper proti Spojenému království, č. stížnosti 48843/99, body 130-132.

68 Rozsudek Evropského soudu pro lidská práva ze dne 26. 2. 2002, Morris proti Spojenému království, č. stížnosti 38784/97, body 73-75.

69 Rozsudek velkého senátu Evropského soudu pro lidská práva ze dne 16. 12. 2003, Grieves proti Spojenému království, č. stížnosti 57067/00, body 80-81.

70 Ibid., bod 82 . 
námořnictva. ${ }^{71}$ ESLP dále spatřoval problém v tom, že informační zprávy zasílané ředitelem správy Vojenského soudu námořnictva (Naval Court Administration Officer) informující laické členy soudu o jejich právech a povinnostech nejsou dostatečně podrobné a jednoznačné. ${ }^{72}$

V roce 2007 se v př́padu Martin proti Spojenému království Evropský soud pro lidská práva zabýval problematikou jurisdikce vojenských soudů nad civilisty. Stěžovatel byl synem vojáka britské armády umístěného na vojenské základně v Německu, kde se svým otcem žil. V roce 1995 byl Vojenským soudem armády odsouzen za vraždu německé civilistky, která na dané vojenské základně pracovala. ${ }^{73}$ Po vyčerpání opravných prostředků se v roce 1998 obrátil se stížností na Evropskou komisi pro lidská práva. Ta byla týž rok postoupena Evropskému soudu pro lidská práva. ESLP konstatoval porušení čl. 6 odst. 1 Úmluvy o ochraně lidských práv a základních svobod.

Důvodem, proč ESLP v daném případu shledal porušení Úmluvy, byla především skutečnost, že řízení u Vojenského soudu armády probíhalo ještě v době, kdy platila právní úprava, kterou ESLP shledal závadnou v př́padu Findlay. ${ }^{74}$ Evropský soud pro lidská práva se však zabýval i argumentem, zda je v souladu s Úmluvou to, že stěžovatele, jakožto civilistu, soudil v dané situaci vojenský soud namísto civilního. ESLP se odkázal na závěry, k nimž došel v př́padu Ergin proti Tureckeu ${ }^{75}$ a uvedl, že Úmluva nezakazuje souzení civilistů vojenskými soudy, ale jurisdikce vojenských trestních soudů se může vztahovat na civilisty, pouze pokud k tomu existují přesvědčivé důvody postavené na jasném a předvídatelném právním základě. ${ }^{76}$ To, že byl stěžovatel v daném případu souzen vojenským soudem, považoval ESLP za problematické, avšak o tom, zda šlo o porušení Úmluvy, nerozhodl, nebot' porušení Úmluvy našel jinde. ${ }^{77}$

\subsection{Změny vojenského soudnictví Velké Británie vyvolané rozhodnutími ESLP}

Př́pad Findlay vyvolal slovy Jamese Ranta největší změnu britského soudnictví za posledních 300 let. $^{78}$ Přestože se již nějakou dobu v britských právních kruzích mluvilo

71 Rozsudek velkého senátu Evropského soudu pro lidská práva ze dne 16. 12. 2003, Grieves proti Spojenému království, č. stížnosti 57067/00, body 87-89.

72 Ibid., bod 90.

73 Rozsudek Evropského soudu pro lidská práva ze dne 24. 1. 2007, Martin proti Spojenému kerálovství, č. stížnosti 40426/98, body 11-17.

74 Ibid., bod 54.

75 Rozsudek Evropského soudu pro lidská práva ze dne 4. 5. 2006, Ergin proti Turecku, č. stížnosti 47533/99, body 41-47.

76 Rozsudek Evropského soudu pro lidská práva ze dne 24. 1. 2007, Martin proti Spojenému kerálovství, č. stížnosti 40426/98, bod 44.

77 Ibid., bod 45 .

78 RANT, James W. The military justice system and human rights. The RUSI Journal, 2000, roč. 145, č. 2, s. 32. DOI: https://doi.org/10.1080/03071840008446505 
o nedostatcích britského systému vojenského soudnictví, tak teprve posudek Evropské komise pro lidská práva o porušení Úmluvy v př́padu Findlay ve spojení s řadou stížností k ESLP v obdobných věcech ${ }^{79}$ vedl k rychlé reformě britského vojenského soudnictví. ${ }^{80}$ Ta se projevila ve formě zákona o ozbrojených silách z roku 1996 (Armed Forces Act 1996), který nabyl účinnosti 1. 4. 1997. Tento předpis vytvořil služební prokuraturu (Service Prosecution Authority) u každé složky ozbrojených sil, která měla nově řídit přípravné řízení a rozhodovat o podání obžaloby. Pravomoc vybírat členy poroty vojenských soudů přsšla na ředitele nově vytvořené vojenské soudní služby, tedy civilní orgán státní správy vojenských soudů podřízený ministerstvu obrany. Velící důstojník rovněž ztratil pravomoc přezkoumávat a měnit rozsudky vojenských soudů. Judge advocate se stal plnohodnotným členem soudu s pravomocí rozhodovat ve věci samé. ${ }^{81}$

V roce 2001 došlo ke zřízení Odvolacího soudu pro sumární řízení, jakožto vojenského správního soudu přezkoumávajícího rozhodnutí velících důstojníků o kázeňských deliktech př́slušníků ozbrojených sil. Tento soud byl zřízen, aby zajišt'oval soulad rozhodování o kázeňských deliktech s Úmluvou po schválení Zákona o lidských právech (Human Rights Act) z roku 1998, který Úmluvu o lidských právech a základních svobodách transformoval do vnitrostátního práva Velké Británie. ${ }^{82}$ Důvod spočíval v tom, že rozhodování velícího důstojníka v sumárním řízení nenaplňovalo definici nezávislého a nestranného tribunálu, bylo neveřejné a obviněný nemohl mít obhájce, což bylo v rozporu s čl. 6 odst. 1 a odst. 3 Úmluvy.

Vytvoření Odvolacího soudu pro sumární řízení lze považovat za důsledek judikatury Evropského soudu pro lidská práva, konkrétně rozsudků v prŕpadech Albert a Le Comptproti Belgii ${ }^{83}$ a Özüürk proti Némeck $u^{84}{ }^{84}$ ESLP v nich totiž dovodil, že právo na nezávislý a nestranný tribunál podle čl. 6 odst. 1 Úmluvy, jakož i jeho trestněprávní aspekty uvedené v článku 6 odst. 3 Úmluvy, se vztahuje i na řízení o přestupcích. ESLP tedy svou judikaturou rozšíríl záběr Úmluvy i na správní delikty, mezi něž patř́ i delikty kázeňské.

Zatímco nedostatky původního modelu britského vojenského soudnictví vnímala britská odborná právnická veřejnost již před rozsudkem Evropského soudu pro lidská práva

79 Viz např. Rozsudek Evropského soudu pro lidská práva ze dne 24. 9. 1997, Coyne proti Spojenému království, č. stížnosti 25942/94 a rozsudek Evropského soudu pro lidská práva ze dne 18. 2. 1999, Cable a ostatni proti Spojenému království, č. stížnosti 24436/94.

80 RANT, James W. The military justice system and human rights. The RUSI Journal, 2000, roč. 145, č. 2, s. 33.

81 ANDREU-GUZMAN, Frederico. Military jurisdiction and international law. Geneva: International Commission of Jurists, 2004, s. 345-346. ISBN 978-9290371021.

82 RANT, James W. The military justice system and human rights. The RUSI Journal, 2000, roč. 145, č. 2, s. 34-35. DOI: https://doi.org/10.1080/03071840008446505

83 Rozsudek Evropského soudu pro lidská práva ze dne 10. 2. 1983, Albert a Le Comptproti Belgï, č. stížností $7299 / 75$ a $7496 / 75$, bod 29.

84 Rozsudek velkého senátu Evropského soudu pro lidská práva ze dne 21. 2. 1984, Öz̨ürk proti Nèmecku, č. stížnosti 8544/79, bod 56 . 
ve věci Findlay, tak rozsudky ESLP v případech Morris a Grieves představovaly šok, nebot' reformovaný systém vojenského soudnictví byl vnímán jako adekvátní. ${ }^{85}$

Sněmovna lordů, sloužící v dané době jako nejvyšší stupeň soudní soustavy Velké Británie, podrobila ve svém rozsudku ve věci Regina proti Boyd z roku 2002 rozhodnutí Evropského soudu pro lidská práva ve věci Morris tvrdé kritice, především ve vztahu k údajnému nedostatku nezávislosti laických členů vojenských soudů a roli přezkumného orgánu Rady obrany. Lord Bingham poukázal na to, že ESLP v rozsudku ve věci Morris nevzal v potaz některé okolnosti zajišt'ující nezávislost laických členů Vojenského soudu a skutečnost, že přezkumný orgán Rady obrany může změnit rozhodnutí soudu jen ve prospěch obžalovaného. ${ }^{86}$

Šlo o jeden z vzácných případů, kdy se vrcholné britské soudy takto ostř́e vymezily proti judikatuře ESLP, $\mathrm{k}$ níž obvykle přistupují se značným respektem. ${ }^{87}$ Ve vztahu k vojenskému soudnictví šlo o ojedinělý případ. V záležitostech týkajících se civilních soudů se však tento konflikt několikrát opakoval, např. když britský Nejvyšší soud ve svém rozsudku Regina proti Horncastle ${ }^{88}$ kritizoval závěry rozhodnutí ESLP ve věci Al-khawaja ohledně britské doktríny důkazu z doslechu v trestních př́ípadech. ${ }^{89}$

Nutno podotknout, že ESLP rozsudek britské Sněmovny lordů ve věci Regina proti Boyd zohlednil při projednávání př́padu Cooper. ${ }^{90}$ Lze spekulovat o tom, že mohl být príćčnou, proč ESLP ve věci Cooper již nepovažoval existenci přezkumného orgánu Rady obrany za explicitní porušení práva na nezávislý tribunál, zatímco v př́padu Morris dospěl k opačnému závěru. ${ }^{91}$ Argumenty britské Sněmovny lordů vzal ESLP v potaz i v otázce nezávislosti laických členů Vojenského soudu RAF, avšak odklon od svého závěru ve věci Morris odůvodnil především odlišnou právní úpravou jejich postavení oproti laickým členům Vojenského soudu armády, řešeného v př́padu Morris. ${ }^{92}$

85 RANT, James W. The military justice system and human rights. The RUSI Journal, 2000, roč. 145, č. 2, s. 33. DOI: https://doi.org/10.1080/03071840008446505

86 Rozsudek Sněmovny lordů Spojeného království Velké Británie a severního Irska ze dne 18. 7. 2002, Regina proti Boyd and Others, [2002] UKHL 31.

87 KRISCH, Nico. Beyond Constitutionalism: The Pluralist Structure of Postnational Law. Oxford: Oxford University Press, 2010, s. 135-136. ISBN 978-0199659968.

88 Rozsudek Nejvyššího soudu Spojeného království Velké Británie a severního Irska ze dne 9. 12. 2009, Regina proti Horncastle \& Others, [2009] UKSC 14.

89 MAK, Elaine. Judicial Decision-Making in a Globalised World: A Comparative Analysis of the Changing Practices of Western Highest Courts. Oxford: Hart Publishing, 2013, s. 165. ISBN 978-1-84946-554-0.

90 Rozsudek velkého senátu Evropského soudu pro lidská práva ze dne 16. 12. 2003, Cooperproti Spojenému království, č. stížnosti 48843/99, body 63-76.

91 MAK, Elaine. Judicial Decision-Making in a Globalised World: A Comparative Analysis of the Changing Practices of Western Highest Courts. Oxford: Hart Publishing, 2013, s. 164-165. ISBN 978-1-84946-554-0.

92 Rozsudek velkého senátu Evropského soudu pro lidská práva ze dne 16. 12. 2003, Cooper proti Spojenému království, č. stížnosti 48843/99, body 123-125. 
Každopádně nedostatky vytknuté v rozhodnutích ESLP ve věcech Morris a Grieves znamenaly, že se systém britského vojenského soudnictví bude muset změnit. Reforma vojenského soudnictví se stala součástí zákona o ozbrojených silách z roku 2006 (Armed Forces Act 2006)..$^{93}$

Došlo ke zrušení funkce stálého laického předsedy v řízení u Vojenského soudu. Ř́zení u Vojenského soudu nově předsedal judge advocate. ${ }^{94}$ Přestože ESLP nevadilo, že stálý předseda byl vojenský důstojník a právní laik, tak daná skutečnost byla stěžovateli opakovaně napadána ${ }^{95}$ a tudíž vnímána jako riziko. Navíc Vojenský soud britské armády ve věci Regina proti McKendry dospěl k závěru, že existence pozice stálého laického předsedy je v rozporu s Úmluvou o ochraně lidských práv a svobod, a přestože tento závěr v následných př́padech odmítly soudy vyšší instance, ${ }^{96}$ tak institut stálých laických předsedů přestal být užíván. Vzhledem k tomu, že existence pozice stálého předsedy poroty vojenského soudu není řešena žádnou z komparačních otázek, tak postrádá smysl zabývat se tím, zda zánik této funkce lze označit za nepř́imý důsledek judikatury ESLP.

Vojenský soud se nově stal soudem stálým. ${ }^{97}$ Vzhledem $\mathrm{k}$ tomu, že ESLP ve věci Grieves vytknul, že Vojenský soud námořnictva je svoláván jako ad hoc tribunál, ${ }^{98}$ lze to označit za př́mý důsledek rozhodnutí ESLP. Vojenský soud se rovněž stal společným pro všechny složky ozbrojených sil, v důsledku čehož došlo k vytvoření jednotné soustavy vojenských soudů pro celé ozbrojené síly. Evropský soud pro lidská práva sice nikde neuvedl, že soustava vojenských soudů musí být společná pro všechny složky ozbrojených sil, ale já tuto změnu považuji za neprrímý důsledek jeho judikatury.

V prrípadu Grieves v části rozsudku týkající se judge advocates totiž ESLP uvedl, že zvláštní právní úprava vojenského soudnictví některé ze složek ozbrojených sil lišící se od právní úpravy vojenských soudů ostatních složek ozbrojených sil musí být přesvědčivě zdůvodněna, což podle názoru ESLP nebylo splněno. ${ }^{99} \mathrm{~V}$ situaci, kdy prakticky nelze mít odlišnou úpravu pro vojenské soudy jednotlivých složek ozbrojených sil, tak zaniká hlavní důvod pro to, aby jednotlivé složky ozbrojených sil měly vlastní soustavy vojenských soudů.

93 Sections 50-309 of Armed Forces Act 2006 [Spojené království Velké Británie a Severního Irska] as amended.

94 Section 159 of Armed Forces Act 2006 [Spojené království Velké Británie a Severního Irska] as amended.

95 Viz např. Rozsudek Evropského soudu pro lidská práva ze dne 26. 2. 2002, Morris proti Spojenému království, č. stížnosti 38784/97, bod 42 a rozsudek velkého senátu Evropského soudu pro lidská práva ze dne 16. 12. 2003, Cooper proti Spojenému království, č. stížnosti 48843/99, bod 88.

96 Rozsudek Sněmovny lordů Spojeného království Velké Británie a severního Irska ze dne 18. 7. 2002, Regina proti Boyd and Others, [2002] UKHL 31.

97 Paragraph 19 of Armed Forces Act 2006 Explanatory Notes, Overview of the Act [Spojené království Velké Británie a Severního Irska].

98 Rozsudek velkého senátu Evropského soudu pro lidská práva ze dne 16. 12. 2003, Grieves proti Spojenému království, č. stížnosti 57067/00, body 80-81.

99 Ibid., body 88-89. 
Podle rozhodnutí Evropského soudu pro lidská práva ve věci Grieves nesmí judge advocate vykonávat úkoly mimo vojenské soudy. ${ }^{100}$ To, společně s tím, že se Vojenský soud stal soudem stálým a společným pro celé ozbrojené síly, mělo za následek, že Vojenský soud získal soudního funkcionáře. Judge Advocate General, působící dříve jako velitel právní služby, se stal předsedou Vojenského soudu a dostal na starosti ř́zení jeho fungování. Pravomoc Judge Advocate General podat opravný prostředek proti rozhodnutí vojenských soudů přešla v souvislosti s tím na generálního prokurátora, nebot' by nebylo logické, aby kromě obžalovaného mohl opravný prostředek proti rozhodnutí soudu podávat pouze předseda daného soudu. ${ }^{101}$ Považuji to tedy za nepřímý důsledek judikatury ESLP.

Další změnu v oblasti přezkumu rozhodnutí vojenských soudů představovalo zrušení přezkumného orgánu Rady obrany, který ESLP ve věci Morris shledal jako rozpornou s Úmluvou ${ }^{102}$ a ve věci Cooper ji označil jako problematickou. ${ }^{103}$ Tato změna se však nedotýká žádné ze srovnávaných oblastí.

Jak již bylo uvedeno výše, civilisté podléhají jurisdikci britských vojenských soudů i po rozhodnutí ESLP ve věci Martin. Působnost vojenských soudů je však nově omezena pouze na trestné činy, které civilisté podléhající vojenskému soudnictví spáchajî na území Velké Británie. V roce 2009 totiž došlo ke zrŕizení Služebního civilního soudu (Service Civilian Court), který rozhoduje o trestných činech, které civilisté podléhající služební kázni spáchají v zahraničí, ${ }^{104}$ jako tomu bylo v př́ípadě Martin. Jde o soud civilní, stojící mimo soustavu vojenských soudů. Nicméně tato úprava je částí právnické veřejnosti stále hodnocena jako problematická. ${ }^{105}$

Jurisdikci vojenských soudů nad civilisty v zahraničí označil ESLP v případu Martin za problematickou, ale neprohlásil jí výslovně za porušení Úmluvy, nebot' její porušení již v př́ípadu našel jinde. Omezení územní působnosti britských vojenských soudů ve vztahu $\mathrm{k}$ civilistům podléhajícím služební kázni tedy lze brát jako nepřímý důsledek jeho rozhodnutí, vyvolané obavou, že v další obdobném př́ípadu by v tomto mohl porušení Úmluvy nalézt.

100 Rozsudek velkého senátu Evropského soudu pro lidská práva ze dne 16. 12. 2003, Grieves proti Spojenému království, č. stížnosti $57067 / 00$, body 82 .

101 Section 272 of Armed Forces Act 2006 [Spojené království Velké Británie a Severního Irska] as amended.

102 Rozsudek Evropského soudu pro lidská práva ze dne 26. 2. 2002, Morris proti Spojenému království, č. stížnosti 38784/97, body 73-75.

103 Rozsudek velkého senátu Evropského soudu pro lidská práva ze dne 16. 12. 2003, Cooper proti Spojenému království, č. stížnosti 48843/99, body 130-132.

104 Section 51 of Armed Forces Act 2006 [Spojené království Velké Británie a Severního Irska] as amended.

105 FIDELL, Eugene R. Military justice: a very short introduction. Oxford: Oxford University Press, 2016. Very short introductions, s. 34-35. ISBN 978-0-19-930349-6. 
Abych své poznatky rekapituloval, tak mohu uvést, že největší význam pro britské vojenské soudnictví mělo rozhodnutí ESLP ve věci Findlay. Jeho přímým důsledkem byly změny ve čtyřech srovnávaných oblastech. Kroky přijaté v reakci na dané rozhodnutí vedly k tomu, že judge advocates, jakožto soudci vojenských soudů, získali rozhodovací pravomoci, právo rozhodnout o podání obžaloby přešlo z velícího důstojníka na prokuraturu, výběr laických členů vojenských soudů nově prováděl orgán státní správy vojenských soudů a velící důstojník ztratil právo přezkoumat a změnit rozsudek Vojenského soudu.

Vytvoření Odvolacího soudu pro sumární řízení, jakožto vojenského správního soudu, považuji za přímý, byt' opožděný důsledek rozhodnutí ESLP ve věcech Albert a Le Compte proti Belgii a Öztürk proti Nèmecku. ESLP v nich rozšířil požadavky kladené v čl. 6 odst. 1 a odst. 3 Úmluvy na řízení v trestních věcech na řízení o správních deliktech. Za nepřímého původce omezení územní působnosti britských vojenských soudů na civilisty podléhající služební kázni lze pak označit rozsudek ESLP ve věci Martin.

Rozsudek velkého senátu ESLP ve věci Grieves prrímo vedl ke změně v jedné srovnávané oblasti a nepřímo ke změnám v dalších dvou oblastech. Přímým důsledkem tohoto rozhodnutí bylo, že vojenské soudy prvního stupně se staly soudy stálými. Nepřímé důsledky spočívaly ve vytvoření jednotné soustavy vojenských soudů pro celé ozbrojené síly a přechod pravomoci podat opravný prostředek proti rozhodnutí vojenských soudů z Judge Advocate General na generálního prokurátora.

V první časti článku jsem zjistil, že mezi roky 1996 a 2020 došlo ve vojenském soudnictví Velké Británie ke změnám ve dvanácti zkoumaných oblastech. V této části jsem zjistil, že devět z těchto dvanácti změn bylo důsledkem judikatury ESLP, přičemž změny v šesti zkoumaných oblastech byly jejím prímým důsledkem a změny ve třech zkoumaných oblastech jejím nepř́mým důsledkem.

\subsection{Změny ve vojenském soudnictví Velké Británie vyvolané jinými faktory než judikaturou ESLP}

Evropský soud pro lidská práva tedy prrímo či nepřímo zpơsobil změny v devíti ze dvanácti sledovaných oblastech systému vojenského soudnictví Velké Británie. V této části se budu věnovat tomu, co způsobilo změny ve zbylých třech sledovaných oblastech, tj. orgánu vybírajícím soudce vojenských soudů, orgánu odvolávající soudce vojenských soudů a toho, že se jurisdikce vojenských soudů rozšírila i na trestné činy vojáků spáchané bez souvislosti se službou v ozbrojených silách.

Změna ve způsobu výběru soudců obecných i zvláštních soudů Velké Británie, jakož i změna v procesu jejich odvolávání jsou důsledkem zákona o ústavní reformě (Constitutional Reform Act) z roku 2005. Tento zákon byl přijat za účelem posílení a kodifikace principu soudcovské nezávislosti a také vyvážení dělby moci ve státě. 
Dosavadní systém, v němž ministr spravedlnosti rozhodoval o jmenování i odvolávání soudců, přičemž působil zároveň jako člen vlády i jako soudce Sněmovny lordů, byl vnímán jako neefektivní, zastaralý a problematický z pohledu soudcovské nezávislosti a dělby moci. ${ }^{106}$

Zákon proto mimo jiné přenesl pravomoc vybírat soudce na Komisi pro výběr soudců a omezil pravomoc ministra spravedlnosti odvolávat soudce tím, že chování soudců začal vyšetřovat nezávislý Úřad pro vyšetřování justičních stížností. Ministr spravedlnosti navíc od účinnosti zákona o ústavní reformě může soudce odvolat z funkce, jen pokud s tím souhlasí Lord Chief Justice. Je však nutno ještě ověřit, zda přijetí změn obsažených v zákonu o ústavní reformě nevyvolala alespoň nepř́imo reakce na judikaturu ESLP.

Skutečnost, že judge advocates, tedy soudce vojenských soudů, vybíral ministr spravedlnosti, nepovažoval ESLP za problematickou, nebot' v rozsudku ve věci Cooper uvedl, že míra nezávislosti judge advocates je dostatečná. ${ }^{107}$ To je ostatně v souladu s ustálenou judikaturou ESLP, podle níž nepředstavuje výběr a jmenování soudců orgánem moci výkonné porušení Úmluvy. ${ }^{108}$ Lze tedy konstatovat, že změna v orgánu vybírajícím soudce britských vojenských soudů nebyla přímým ani nepřímým důsledkem judikatury ESLP.

K problematice toho, že ministr spravedlnosti mohl odvolat judge advocate z funkce, se ESLP ve své judikatuře týkající se britských vojenských soudů nevyjadřoval. V př́padu Brudnická a dalši proti Polsku však ESLP shledal porušení Úmluvy mimo jiné $\mathrm{v}$ tom, že ministr spravedlnosti měl pravomoc odvolat soudce námořních senátů (Izba Morzska). ${ }^{109}$ Tento rozsudek byl však vynesen až v březnu 2005, zatímco zákon o ústavní reformě byl předložen v britském parlamentu již v únoru 2004. ${ }^{110}$ Přestože se někteří autoři domnívají, že vznik zákona o ústavní reformě byl motivován snahou o zajištění souladu právní úpravy s Úmluvou, ${ }^{111}$ ESLP se k otázce odvolávání soudců

106 WOODHOUSE, Diana. The Constitutional Reform Act 2005 - defending judicial independence the English way. International Journal of Constitutional Law, 2007, roč. 5, č. 1, s. 154.

107 Rozsudek velkého senátu Evropského soudu pro lidská práva ze dne 16. 12. 2003, Cooper proti Spojenému království, č. stížnosti 48843/99, bod 117.

108 Viz např. Rozsudek Evropského soudu pro lidská práva ze dne 28. 6. 1984, Campbell a Fell proti Spojenému království, č. stížností 7819/77 a 7877/77, bod 79, rozsudek Evropského soudu pro lidská práva ze dne 11. 9. 2006, Sacilor-Lormines proti Francii, č. stížnosti 65411/01, bod 67 a rozsudek Evropského soudu pro lidská práva ze dne 3. 7. 2007, Flux proti Moldavsku (č. 2), č. stížnosti 31001/03, bod 27.

109 Rozsudek Evropského soudu pro lidská práva ze dne 3. 3. 2005, Brudnická a dalši proti Polsku, č. stížnosti $54723 / 00$, bod 41.

110 Paragraph 409 of Constitutional Reform Act 2005 Explenatory Notes [Spojené království Velké Británie a Severního Irska].

111 Viz napr. WOODHOUSE, Diana. The Constitutional Reform Act 2005 — defending judicial independence the English way. International Journal of Constitutional Law, 2007, roč. 5, č. 1, s. 154. 
vojenských soudů z funkce $\mathrm{v}$ dané době ještě nevyjádřil a jeho judikaturu tedy nemohu považovat za př́ćčinu této změny.

Zákon o ozbrojených silách z roku 2006 rozšíríl působnost britských vojenských soudů i na trestné činy př́slušníků ozbrojených sil spáchaných bez souvislosti se službou v ozbrojených silách. ${ }^{112} \mathrm{~V}$ prrípadech týkajících se britských vojenských soudů se ESLP otázkou věcné působnosti vojenských soudů nezabýval. Není mi známo ani žádné jiné rozhodnutí ESLP zabývající se rozsahem věcné trestní působnosti vojenských soudů, nebot' v otázkách působnosti vojenských soudů řešil ESLP pouze působnost osobní. ${ }^{113}$ Důvod pro rozšíření věcné působnosti britských vojenských soudů i na trestné činy př́islušníků ozbrojených sil nemající souvislost s vojenskou službou není výslovně uveden. Lze spekulovat, že důvodem mohla být snaha zajistit vojenským soudům dostatek př́padů a také snaha o odstranění nejasností a kompetenčních sporů mezi vojenskými a civilními soudy, které provázejí omezení věcné působnosti vojenských soudů na trestné činy spojené s výkonem služby v ozbrojených silách. ${ }^{114}$

\section{Závěr}

Na závěr shrnuji obecné požadavky, které ESLP stanovil na podobu vojenských soudů. Poté zrekapituluji, v jakých oblastech britského vojenského soudnictví došlo ke změně v důsledku judikatury ESLP. Následně posoudím míru vlivu této na současnou podobu systému vojenského soudnictví Velké Británie.

Z požadavků ESLP na podobu vojenských soudů vyplývá, že alespoň jeden člen vojenského soudu musí být právní profesionál, musí mít podíl na rozhodování vojenského soudu, jakož i postavení a záruky nezávislosti ekvivalentní soudci obecného soudu. Soudce vojenského soudu může být př́slušníkem ozbrojených sil, ale musí být právním profesionálem, mít adekvátní hodnost a nemůže plnit úkoly mimo vojenský soud a po dobu služby u vojenského soudu nesmí podléhat vojenské kázni a postoupnosti velení. $^{115}$

Laičtí členové vojenského soudu, kteří jsou příslušníky ozbrojených sil, musí disponovat ještě silnějšími zárukami nezávislosti než jejich civilní protějšky u obecných soudů. Musí být důkladně poučeni o právních otázkách právním profesionálem a za své rozhodování u vojenského soudu nesmí být trestáni ani o něm podávat zprávy. Přestože je možné,

112 FIDELL, Eugene R. Military justice: a very short introduction. Oxford: Oxford University Press, 2016 , s. 44. ISBN 978-0-19-930349-6.

113 Viz např. Rozsudek Evropského soudu pro lidská práva ze dne 25. 9. 2001, Sabiner proti Turecku, č. stížnosti 29279/95, body 33-47.

114 MORRIS, Lawrence J. Military Justice: A Guide to the Issues. Santa Barbara: Praeger Security International, 2010, s. 37. ISBN 978-0275993665.

115 Rozsudek velkého senátu Evropského soudu pro lidská práva ve věci ze dne 20. 11. 2014, Jaloud proti Nizozemsku, č. stížnosti 47708/08, bod 196. 
aby laický prvek u vojenských soudů měl charakter soudní poroty, tak vojenské soudy nesmí mít povahu ad hoc tribunálu. Laické členy soudu navíc musí vybírat dostatečně nezávislý orgán, přičemž velící důstojník tuto charakteristiku nesplňuje.

Velící důstojník také nesmí rozhodovat o podání obžaloby, to může učinit jen právní profesionál, který je součástí orgánu veřejné žaloby. Rozsudek vojenského soudu navíc nesmí měnit ani rušit žádný orgán, který sám není soudem. Vojenské soudy rovněž mohou soudit civilisty jen ve výjimečných př́padech.

Evropský soud pro lidská práva tedy stanovil řadu požadavků na fungování vojenských soudů, které se navíc tykají klíčových aspektů jako je jejich složení a fungování, jakož i průběh řízení. Jak jsem již uvedl v první části, vojenské soudnictví Velké Británie prošlo mezi lety 1996 a 2020 radikální proměnou. Celkem jsem identifikoval dvanáct změn, k nimž v dané době došlo ve vojenském soudnictví Velké Británie.

Ve druhé části článku jsem zjistil, že ESLP svou judikaturou vyvolal změny v devíti z dvanácti sledovaných oblastí britského vojenského soudnictví. Šest těchto změn bylo př́mým důsledkem jeho judikatury a další tři změny představovaly důsledek nepř́mý. ESLP tedy vyvolal drtivou většinu změn ve sledovaných oblastech. Z toho dospívám k závěru, že Evropský soud pro lidská práva svou judikaturou významně ovlivnil podobu vojenského soudnictví Velké Británie. Lze ho tedy považovat za hlavního původce reforem, které transformovaly historický systém vojenského soudnictví Velké Británie do jeho současné podoby. 